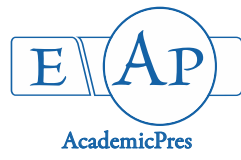

\title{
Evaluation of Different RNA Extraction Methods from Agropatch Suppressor Assay for Small Quantities of Plant Tissue and Their Application for Analysis of Gene Expression
}

\author{
Aminallah TAHMASEBI ${ }^{1}$, Amir G. SHAHRIARI $^{2 *}$ \\ ${ }^{1}$ Shiraz University, Plant Virology Research Center, Bajgah, Shiraz,Iran; Tahmasebi_qash@hotmail.com \\ ${ }^{2}$ Higher Education Center of Eghlid, Department of Agriculture and Natural Resources, Hafez Street, Eghlid, \\ Iran;Shahriari.ag@eghlid.ac.ir (*correspondingauthor)
}

\begin{abstract}
The agroinfiltration assay provides fast and efficient way to transiently express genes into plant cells by Agrobacterium tumefaciens. Extraction of RNA of high quality and sufficient amounts is prerequisite for gene expression studies such as quantitative Real Time PCR (q-PCR) from infiltrated areas in agropatch suppressor assay with small quantities of plant tissue. To attain prime RNA extraction from small tissues of infiltrated $N$. benthamiana plants with Potato virus A helper component proteinase viral suppressor protein, the efficiency of three RNA extraction methods (LiCl, TRIzol reagent and commercial kit) was evaluated. The total RNA yield with $\mathrm{LiCl}$ method was 2.83 and 33.2-fold greater than that of TRIzol reagent and commercial kit, respectively. Also, total RNA yield using TRIzol reagent was 11.7-fold higher than that with commercial kit. The A260/A280 ratio mean for TRI reagent (1.95) and kit (1.9) extractions were within the optimum range.q-PCR revealed that the cycle threshold values of housekeeping gene, EIF-1 $\alpha$ and target genes AGO1 and ATG6 for RNA extracted using $\mathrm{LiCl}$ and kit were 1.07 to 1.3 and 1.02 to 1.12 times higher than those evaluated with the TRIzol method. Overall, TRIzol method showed the most effective approach for obtaining RNA from $N$. benthamiana patches in gene expression studies.
\end{abstract}

Keywords: agro infiltration; q-PCR; RNA extraction; RNA silencing; small tissue samples; TRIzol; viral suppressors of RNA silencing

\section{Introduction}

Plant viruses are obligate intracellular parasites that recruit host machinery to accomplish their life cycle. Following viral invasion, plants can defend themselves through a variety of mechanisms including RNA silencing as a natural antiviral defense response. RNA silencing can decrease virus accumulation in the primary infected cells and limit the following virus cell-to-cell and long-distance movement (Ding and Voinnet, 2007). To counteract host RNA silencing, viruses have evolved diversified mechanisms, including expression of RNA silencing suppressors (RSS) which is one of the most common strategy in plant viruses (Ding et al., 2004; Roth et al., 2004; Voinnet, 2005; Ding and Voinnet, 2007). A large number of RSS proteins with diverse structures and functions have been identified in many plant viruses and some animal viruses (Brigneti et al., 1998; Kasschau and Carrington, 1998; Voinnet, 2005; Li and Ding, 2006). Potato virus A (PVA) belongs to Potyviridae (genus Potyvirus), as the largest virus family infecting plants (Urcuqui-Inchima et al., 2001). Similar to other potyviruses, the PAV genome encodes a large polyprotein subsequently cleaved by three virusencodedproteinasesto yield up to ten mature proteins (Urcuqui-Inchima et al., 2001; Rajamäki et al., 2004). Helper component proteinase (HC-Pro) is a multifunctional protein involved in potyvirus replication, cell-to-cell movement and long-distance movement (Rojas et al., 1997; Sáenz et al., 2002), aphid transmission (Pirone and Blanc, 1996), symptom development (Redondo et al., 2001), viral synergism (Wang et al., 2002), inhibition of the endonuclease activity (Ballut et al., 2005), the protease activity (Sahana et al., 2012) of the 20 S proteasome and suppression of RNA silencing-based antiviral defense in plants (Rajamäki et al., 2004). A variety of different assays have been established to identify and characterize viral 
suppressors of RNA silencing (VSR) (Qu and Morris, 2005). One common biological used assay is called "agropatch suppressor assay" carried out by transient expression of candidate virus-encoded gene through the coinfiltration of separate Agrobacterium tumefaciens (agro infiltration) harboring the VSR and a reporter gene such as green fluorescent protein (GFP) into leaves of Nicotiana benthamiana (Johansen and Carrington, 2001).

One major problem is associated with collecting high quality and sufficient amounts from infiltrated area in agropatch suppressor assay with small tissue in gene expression studies. Moreover, it is important for obtaining reliable gene expression data from different genomic approaches such as quantitative Real Time PCR (q-PCR), hybridization microarrays and next generation sequencing (NGS) technologies (Maciel et al., 2011).

The present study was aimed to evaluate three different RNA extraction methods, TRIzol reagent, lithium chloride (LiCl) salt and a commercial kit (S-1010-1, Dena Zist Asia, Iran). The research describes the results of the evaluation focusing mainly on the yield and purity of RNA extracted by these methods and the performance of the q-PCR from small patches of $N$. benthamiana plants co-infiltrated with PVA HC-Pro viral suppressor and GFP reporter gene.

\section{Materials and Methods}

Plantmaterial

$N$. benthamiana plants were grown with a photoperiod $16 \mathrm{~h}$ light / $8 \mathrm{~h}$ dark, minimum temperature of $18 \pm 4{ }^{\circ} \mathrm{C}$ and $80 \%$ humidity.

\section{Constructs}

The cDNA of PVA-HC-Pro ORF was cloned into a pDONRTM/Zeo vector (Life technology). Then, confirmed clones were recombined into the Gateway (Invitrogen) destination vector pGWB17 (Nakagawa et al., 2007) with a C-terminal myc tag and N-terminal $35 \mathrm{~S}$ promoter. Agrobacterium strain $\mathrm{C} 58 \mathrm{C} 1$ was used in this experiment. For expression of the GFP, the $A$. tumefaciens transformed with a binary vector p35-GFP was uesd (Germundsson et al., 2007).

\section{Agropatch assay}

Agrobacterium cultures harboring PVA HC-Pro, empty plasmid (EP) and GFP constructs were inoculated into 3-ml YEP broth culture and incubated at $28{ }^{\circ} \mathrm{C}$ for $20 \mathrm{~h}$ with shaking. One $\mathrm{ml}$ from these cultures was inoculated into 50 $\mathrm{ml}$ YEP broth cultures with the antibiotics, acetosyringone (20 $\mu \mathrm{M}$ final concentration) and $0.5 \mathrm{M}$ morpholineethanesulfonic acid (MES), pH 5.6. Cultures $\left(\mathrm{OD}_{600} ; 0.5\right)$ were pelleted by centrifugation at $3,500 \mathrm{~g}$ for 5 min and re-suspended in induction buffer containing 10 $\mathrm{mM} \mathrm{MgCl} 2,10 \mathrm{mM}$ MES, $\mathrm{pH}$ 5.6, and $150 \mu \mathrm{M}$ acetosyringone. Agrobacterium cultures diluted in induction buffer and were mixed with an agrobacterium culture containing GFP to infiltrate $N$. benthamiana leaves at six- to eight-week-stage.

GFP detection

GFP fluorescence in $N$. benthamiana leaves was checked using a hand-held long-wave UV lamp UVL-56 (UV Products). Fifty milligrams from green area of leaves indicating GFP expression observed by UV lamp was detached to extract RNA. Each assay was repeated three times.

\section{$R N A$ extraction methods \\ LiCl Protocol}

Fifty milligrams of leaf tissue were ground to a fine powder in liquid nitrogen and $1.000 \mu \mathrm{l}$ of extraction buffer ( $500 \mu \mathrm{l}$ of $\mathrm{LiCl}$ buffer and $500 \mu \mathrm{l}$ of phenol $\mathrm{pH}$ 8.0) were added. The tube was vortexed vigorously for $1 \mathrm{~min}$ and then placed on ice until all tubes have been completed. The tubes were then incubated for $5 \mathrm{~min}$ at $60{ }^{\circ} \mathrm{C}$, followed by centrifugation for $10 \mathrm{~min}$ at $\max$ speed at $4{ }^{\circ} \mathrm{C}$. The upper phase was collected in to a new tube and $600 \mu \mathrm{l}$ of chloroform-isoamyl alcohol $(24: 1 ; \mathrm{v} / \mathrm{v})$ was added to the tube and centrifuged $10 \mathrm{~min}$ at $\max$ speed at $4{ }^{\circ} \mathrm{C}$. The supernatant was transferred into a new micro centrifuge tube and after incubation at $65^{\circ} \mathrm{C}$ for $15 \mathrm{~min}, 50 \mu \mathrm{l}$ of $5 \mathrm{M}$ $\mathrm{NaCl}$ and $63 \mu \mathrm{l}$ of $40 \%$ polyethylene glycol 8.000 (w/v) was added and vortexed for $1 \mathrm{~min}$. They were centrifuged for 10 min at max speed at $4{ }^{\circ} \mathrm{C}$ (the supernatant contains small RNAs and the pellet consists of large RNA). Finally, supernatant was discarded and when the pellet dried, it was re-suspended in $20 \mu \mathrm{l}$ RNase-free water.

\section{TRIzolprotocol}

Fifty milligrams of leaf tissue were placed in a $1.5 \mathrm{ml}$ microfuge tube and finely ground in liquid nitrogen. Then, $1.5 \mathrm{ml}$ of TRIzol was added to each tube and after vigorous mixing; the resulting mixture was vortexed and incubated at room temperature for $5 \mathrm{~min}$ and spun at $12.000 \mathrm{~g}$ for 10 min. Supernatant was removed to new $1.5 \mathrm{ml}$ tube with 0.4 $\mathrm{ml}$ of chloroform and shook vigorously by hand for 15 seconds. They were kept at room temperature for $10 \mathrm{~min}$ and centrifuged at $12,000 \mathrm{rpm}$ for $10 \mathrm{~min}$ at $4{ }^{\circ} \mathrm{C}$. The supernatant was transferred to a new $1.5 \mathrm{ml}$ tube and an aliquot of $500 \mu \mathrm{l}$ isopropanol was added and the resulting mixture incubated for $10 \mathrm{~min}$ at room temperature, followed by centrifugation at $12.000 \mathrm{~g}$ for $20 \mathrm{~min}$ at $4{ }^{\circ} \mathrm{C}$ to pellet total RNA. The pellet was washed with $1.000 \mu \mathrm{l} 75 \%$ ethanol, air-dried for $5 \mathrm{~min}$ and ultimately, dissolved in 250 $\mu \mathrm{l}$ RNase-free water. $250 \mu \mathrm{l} 4 \mathrm{M} \mathrm{LiCl}$ was added, mixed and put on ice overnight. It was centrifuged at $12.000 \mathrm{~g}$ for 20 min at $4{ }^{\circ} \mathrm{C}$. The pellet contains $\mathrm{m}-\mathrm{RNA}$ and $\mathrm{r}-\mathrm{RNA}$ and the supernatant contains t-RNA and si-RNA and the $5 \mathrm{~S} \mathrm{r}$ RNA. Finally, the pellet was washed (m-RNA) in $70 \%$ ethanol and re-dissolved in RNase free water.

\section{Commercial kit protocol}

Fifty milligrams of leaf tissue were ground to a fine powder in liquid nitrogen and the powder was then placed in 2-ml micro tubes containing $1 \mathrm{ml} \mathrm{DR} 1$ buffer. Then, tissue lysate was homogenized in DR1 buffer for 15 seconds and incubated at room temperature for 5 minutes. The tubes were centrifuged at $10,000 \mathrm{rpm}$ for 10 minutes at $4{ }^{\circ} \mathrm{C}$ and the supernatant was then transferred to a fresh microfuge $(1.5 \mathrm{ml})$ with $200 \mu \mathrm{l}$ chloroform and mixed gently for $1 \mathrm{~min}$. After centrifugation for $10 \mathrm{~min}$ at 12.000 $\mathrm{rpm}$, the top aqueous phase was transferred to a new tube 
350

and equal to half of the volume of the aqueous phase was addedfrom $100 \%$ ethanol. $700 \mu \mathrm{l}$ DR2 was added to the spin column, centrifuged at $13.000 \mathrm{rpm}$ for 1 minute at room temperature. Without adding any solution, the tubes centrifuged one more time at $13.000 \mathrm{rpm}$ for 3 minutes at room temperature and the column was transferred onto a new $1.5 \mathrm{ml}$ microfuge tube and $50 \mu \mathrm{l}$ DR3 buffer was added to the center of the column and incubated at room temperature for 2 minutes. They were centrifuged at 10,000 $\mathrm{rpm}$ for 2 minutes at room temperature and the eluted solution was returned from the previous step onto the center of spin column and the spin column was mounted on the microfuge tube for 2 minutes at room temperature. Finally, the tube was centrifuged at $13,000 \mathrm{rpm}$ for 2 minutes.

\section{Quantification and RNA quality estimation}

The samples were quantified and the absorbance ratios at wavelengths of 230, 260 and $280 \mathrm{~nm}$ were measured using a ND-1000 spectrophotometer (Nanodrop, Wilmington, DE, U.S.A.). Then the purity was detected according to the as the ratio of the absorbance at $260 \mathrm{~nm}$ and $280 \mathrm{~nm}$ (A260 / A280) along with the ratio of the absorbance at $260 \mathrm{~nm}$ and $230 \mathrm{~nm}$ (A260 / A230). The value of $\mathrm{OD}_{260 / 230}$ was used as reference value. Agarose gel electrophoresis was used to assay the RNA for intact $28 \mathrm{~S}$ and $18 \mathrm{~S}$ rRNA. The integrity of total RNA was verified by analyzing approximately $3 \mu \mathrm{g}$ of RNA on $1.0 \%$ (w/v) agarose gel, $75 \mathrm{~mA}$ for $20 \mathrm{~min}$, electrophoresed, stained with ethidium bromide $(\mathrm{EtBr})$ and visualized under UV light to assess the integrity of total RNA bands.

\section{Synthesis of complementary DNA (cDNA)}

RNA samples were treated with DNase I (Invitrogen) following the manufacturer's protocol. $1 \mu \mathrm{g}$ of total RNA was used to synthesize cDNA via reverse transcription according to the first strand cDNA synthesis kit protocol (Parstous Biotechnology, Iran). cDNA was synthesized using $1 \mu \mathrm{l}$ of reverse primer $(10 \mathrm{pmol}), 4 \mu \mathrm{l}$ of $5 \mathrm{x}$ reverse transcriptase buffer, $1 \mu \mathrm{l}$ of M-MuLV RT $\left(100 \mathrm{U}_{\mu} \mathrm{L}^{-1}\right)$ and $9 \mu \mathrm{l}$ of DEPC-treated water and $2 \mu \mathrm{l}$ of $10 \mathrm{mM}$ dNTP mix were mixed in Eppendorf tubes, the mixture was incubated at $42{ }^{\circ} \mathrm{C}$ for 1 hour, and then $10 \mathrm{~min}$ at $70{ }^{\circ} \mathrm{C}$. The synthesized cDNA was stored at $-20^{\circ} \mathrm{C}$ until used.

\section{$q P C R$}

The $A G O 1, E I F-1 \alpha$ and $A T G 6$ expression was analyzed by $\mathrm{q}-\mathrm{PCR}$ using a lineGeneK thermal cycler (Exicycler TM96) apparatus according to the manufacturer's recommendations. The q-PCR primers were designed for the reference gene, i.e. $E I F-1 \alpha, A G O 1$ and autophagy-related 6 gene (ATG6) (Table 1). The q-PCR analyses were performed in $20 \mu \mathrm{l}$ volume containing cDNA (250 ng) template, $10 \mu \mathrm{M}$ of each primer $(0.6 \mu \mathrm{l})$, qPCR SYBR Green master with low ROX (Jena Bioscience, Germany) $(10 \mu \mathrm{l})$ and sterile water (fill up to $20 \mu \mathrm{l}$ ). The genes were analyzed using the following profile: $95^{\circ} \mathrm{C}$ for $2 \mathrm{~min}$, then 40 cycles of $95^{\circ} \mathrm{C}$ for $15 \mathrm{sec}, 60{ }^{\circ} \mathrm{C}$ for $1 \mathrm{~min}$. Data were expressed as cycle threshold $(\mathrm{Ct})$ values. Three biological replicates were used and three technical replicates were performed for each biological replicate.

\section{SDS-PAGE for GFP protein}

The total proteins extracted from the infiltrated $N$. benthamiana patches with agrobacterium cultures harboring HC-Pro or EP mixed with GFP culture were separated by sodium dodecyl sulfate-polyacrylamide gel electrophoresis (SDS-PAGE) using a $12 \%$ polyacrylamide gel (Sambrook and Russell, 2001). Following electrophoresis, the gel was stained using Coomassie brilliant blue.

\section{Statistical analysis}

The data were analyzed statistically using SAS 9.4 software and means were separated by Duncan's multiple range test with probability at $5 \%$ level of significance to estimate the differences among the means of treatments (Duncan, 1951).

\section{Results and Discussion}

Infiltrated $N$. benthamiana leaves with a mixture of $A$. tumefaciens cultures containing $\mathrm{pBinGFP}$ plus either $\mathrm{pBin}$ PVA-HC-Pro or pBin were checked using a hand-held long-wave UV lamp at $5 \mathrm{dpi}$. Infiltrated leaves with a mixture of suspensions containing GFP and PVA-HC-Pro constructs showed GFP expression (Fig. 1). Also, SDSPAGE analysis indicated that GFP with $27 \mathrm{KD}$ size was expressed in $N$. benthamiana in the presence of PVA-HCPro at 5 dpi (Fig. 2).

There were compared three different methods to isolate RNAs from fifty $\mathrm{mg}$ of fresh $N$. benthamiana patches coinfiltrated with PVA HC-Pro or EP plus GFP construct aiming to identify which method is more efficient. In this assay, RNA quality was assessed based on fourcriteria: A260 / 280, A260 / 230, appearance on agarose gel and q-PCR assay.

Considerable differences in quantity and quality of RNA extracted by each of the three methods were identified. As the first criteria for assessing the RNA purity, A260 / A280 ratio mean was recorded as 1.95 with TRIzol reagent, 1.74 with $\mathrm{LiCl}$ method, and 1.9 with DenaZist kit. However, typical values of 1.8-2.1 for A260 / A280 ratio and 2.0-2.2, for the A260 / A230 ratio are generally accepted for purity of RNA (Alemzadeh et al., 2005; Winfrey et al., 1997). The A260 / A280 ratios for TRI reagent and Dena Zist kit extractions were within the optimum range, however the ratio for $\mathrm{LiCl}$ method was lower, implying protein contamination with this method. Also, RNA extracted by TRIzol reagent constantly showed the highest A260 : A280 ratio. A260 / A230 ratio mean was also determined as the other criteria of RNA purity, for purified RNA obtained with TRI reagent (2.06), LiClmethod (1.84) and DenaZist kit (1.98). The value of A260 / A230 ratios for RNA purified with $\mathrm{LiCl}$ method was lower than those of TRI reagent and DenaZist kit extractions.

The lower A260 / A230 values may be due to the high salt content of elution buffer and phenol used in extraction methods (Loulakakis et al., 1996; Schultz et al., 1994). Hence, $\mathrm{LiCl}$ method requires an additional clean-up step (phenol or chloroform-phenol extractions in the presence of about $0.3 \mathrm{M}$ sodium acetate) to improve its purity. Except 
$\mathrm{LiCl}$ method, obtained ratios for other methods were close to the threshold number of 2 and were considered satisfactory.

Visualization of the major ribosomal RNA (18S or $28 \mathrm{~S}$ rRNA) bands and any degradation products, can provide a general information about RNA integrity. Generally, intact 28S: $18 \mathrm{~S}$ rRNA bands and a $28 \mathrm{~S}: 18 \mathrm{~S}$ rRNA intensity ratio of $2: 1$, are indicative of RNA integrity. Therefore, in the present study electrophoresis was performed to further validate the quality (integrity) of RNA extracted using the three different methods. Total RNA from commercial kit and large RNA extracted by TRIzol and $\mathrm{LiCl}$ methods were run on $1.0 \%$ agarose gel electrophoresis (Fig. 3) showed the presence of intact and clearly visible $28 \mathrm{~S}$ and $18 \mathrm{~S}$ rRNA bands, indicative of good quality RNA, extracted by all of the three methods.

However, TRIzol method produced more distinct 28S and $18 \mathrm{~S}$ rRNA bands in agarose gel, than those of the other two methods indicating the ability of this reagent for effective inhibition of RNase activity and maintaining the integrity of the RNA species (Zhu et al., 2012). Table 2 shows the yields of total RNAs extracted from co-infiltrated patches of $N$. benthamiana plants with PVA HC-Pro viral suppressor and GFP reporter gene.

There were large differences in the amount of RNA extracted from 0.05 gram of leaf-tissue, among the three protocols. $\mathrm{LiCl}$ method produced the highest yield of RNA (3,782 ng/ $\mu \mathrm{L})$ (Table 2).

Also, the TRIzol method yielded good RNA quantity $(1.336 \mathrm{ng} / \mu \mathrm{L})($ Table 2$)$. However, the yield of total RNA extracted with DenaZist kit exhibited the lowest mean value (113.9 $\mathrm{ng} / \mu \mathrm{L})$.

The quality of RNA samples with the three methods was assessed for use in q-PCR assay. For this purpose, the expression patterns of house keeping gene, $E I F-1 \alpha$ and target genes $A G O 1$ and $A T G 6$ were analyzed and presented as cycle threshold $(\mathrm{Ct})$ values.

As shown in Figs. 4 and 5, the Ct values obtained from TRIzol, $\mathrm{LiCl}$ and kit methods were $23.09 \pm 1.83,30 \pm 2.2$ and $23.48 \pm 3.3$ for EIF- $1 \alpha, 33.91 \pm 2.12,36.26 \pm 1.7$ and $35.4 \pm 0.85$ for AGO1, 26.51 $\pm 1.08,29.38 \pm 2.51$ and $28.47 \pm 1.06$ for ATG6, and $23.47 \pm 1.92,27.13 \pm 1.34$ and $26.17 \pm 1.28$ for EIF-1 $\alpha$ in ATG6 experiment, respectively. The $\mathrm{Ct}$ values of housekeeping gene, EIF-1a and target genes $A G O 1$ and $A T G 6$ for RNA extracted using $\mathrm{LiCl}$ and kit were 1.07 to 1.3 and 1.07 to 1.12 times higher than those evaluated with the TRIzol method, clearly indicating that RNA extracted with TRI reagent is of higher quality.

In current study, the data obtained by q-PCR revealed lower $\mathrm{Ct}$ values of the housekeeping and target genes, (EIF$1 \alpha, A G O 1$ and $A T G 6)$ for RNA extracted using TRI reagent, compared to those of $\mathrm{LiCl}$ and DenaZist methods (Fig. 4 and 5). The extracted RNA samples need sufficient RNA for use in gene expression analysis such as q-PCR

These results indicated that RNA isolated by our protocols was suitable for q-PCR with no interference in PCR amplification. It allows to study plant genes expression in the green area (indicating GFP expression in the presence of VSR) in response to viral suppressors.

Table 1. Details of specific primers used in this study

\begin{tabular}{cccc}
\hline Gene name & Primer name & Sequence from 5' to 3' & Expected product size (bp) \\
\hline \multirow{2}{*}{ AG01 } & AG01-F & GCCATGGGGCACCTTCTG & 132 \\
& AG01-R & GAGACGAGGAACCAGCCTC & 164 \\
ATG6 & ATG6-F & ACCTGCGTAAAGGAGTTTGCTTC & 135 \\
& ATG6-R & AGAGCTTTGGTCCAACTTTCCTGC & \multirow{2}{*}{ EIFI- $\alpha$} \\
& EIFI- $\alpha-\mathrm{F}$ & AGCTTTACCTCCCAAGTCATC & \\
\hline $\mathrm{F}=$ Forward strand, $\mathrm{R}=$ Reverse strand & EIFI- $-\mathrm{R}$ & AGAACGCCTGTCAATCTTGG &
\end{tabular}

Table 2. Purity and yield* analysis of total RNA from $N$. benthamiana extracted by three different methods

\begin{tabular}{|c|c|c|c|}
\hline Method & Average 260/280 & Average 260/230 & Large RNA yield (ng/ $\mu \mathrm{L})$ \\
\hline TRIzol & $1.95(0.08)^{\mathrm{a}}$ & $2.06(0.09)^{a}$ & $1336^{a}$ \\
\hline $\mathrm{LiCl}$ & $1.74(0.04)^{\mathrm{b}}$ & $1.84(0.08)^{b}$ & $3782^{\mathrm{b}}$ \\
\hline Kit & $1.90(0.09)^{\mathrm{a}}$ & $1.98(0.06)^{c}$ & $113.9^{c}$ \\
\hline
\end{tabular}

Yields and spectrophotometric A260 / A280 and A260 / A230 ratios of total RNA extracted from N. benthamiana plants expressing PVA HC-Pro viral suppressor with different extraction methods. $0.05 \mathrm{~g}$ of tissue was used for each RNA extraction method and quantified in a Nanodrop spectrophotometer. Values are spectrophotometric A260 / A280 and A260 / A230 means (standard deviation (SD)) from a total of nine plants (three plants in three replicates). Means followed by the same letters are not significantly different from each other at $(P=0.05)$ determined by Duncan's Multiple Range Test (DMRT).

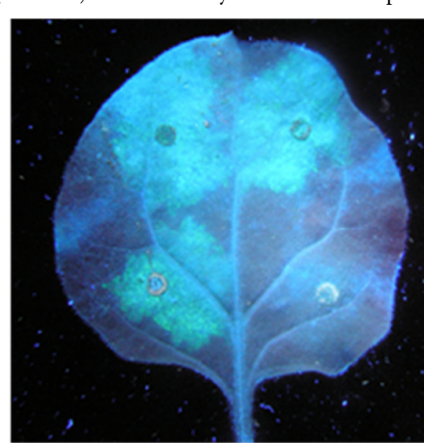

Fig. 1. Leaves of $N$. benthamiana infiltrated with a mixture of $A$. tumefaciens cells harboring pBinGFP plus either pBin PVA-HCPro or pBin (right side, down). Detection of GFP fluorescence in detached $N$. benthamiana leaves was performed using a handheld long-wave UV lamp UVL-56 (UV Products) at 5 dpi 


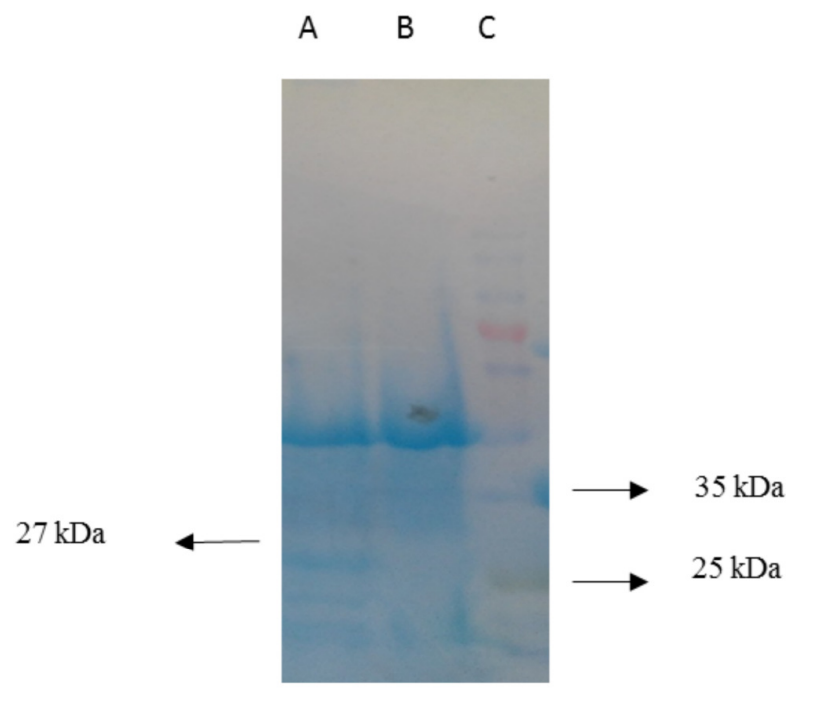

Fig. 2. SDS-PAGE analysis of the expressed GFP in $N$. benthamiana. Total protein samples from pre-infiltrated leaves with PVA HC-Pro and EP (lanes A and B). Lane C, protein size marker. The presence of a band of approximately $27 \mathrm{kDa}$ in the infiltrated leaves with PVA HC-Pro sample but not in EP sample confirmed the expression of GFP in the presence of PVA HC-Pro

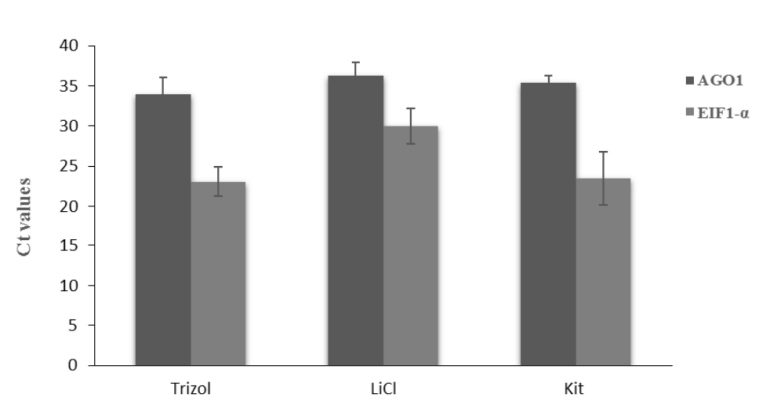

Fig. 4. Graph of cycle threshold $(\mathrm{Ct})$ values of samples tested by the real-time q-PCRfor $A G O 1$ in $N$. benthamiana leaf samples harvested at $5 \mathrm{dpi}$ and extracted using either theTRIzol, $\mathrm{LiCl}$ or commercial kit methods. Total RNA was extracted using either theTRIzol, $\mathrm{LiCl}$ or commercial kit methods. Data were expressed as cycle threshold $(\mathrm{Ct})$ values. Then, $\mathrm{Ct}$ values of housekeeping gene EIF1- $\alpha$ and target gene $A G O 1$ was compared using three different RNA extraction methods by SYBR green real time q-PCR, each consisting of three biological and technical replicates. Error bars represent the standard deviation of the mean

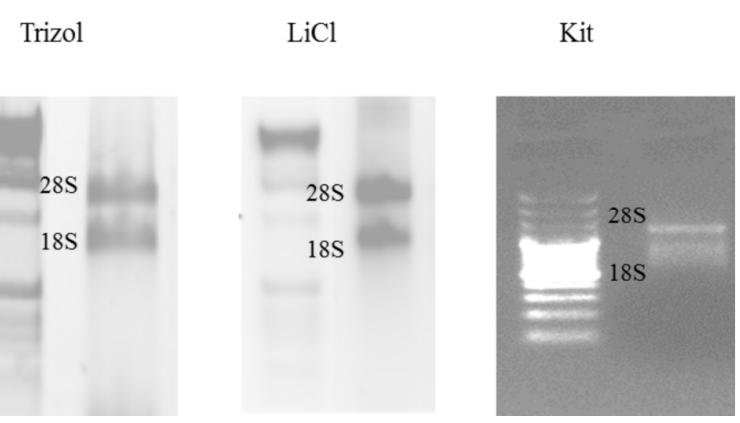

Fig. 3. Comparison of total RNA isolated from $N$. benthamiana plants expressing PVA HC-Pro viral suppressor with different extraction methods. Total RNA was extracted with three different RNA extraction methods. $0.05 \mathrm{~g}$ of tissue was used for each sample and $3 \mu \mathrm{g}$ volume of each sample was loaded on a $1 \%$ agarose gel (gel stained with ethidium bromide)

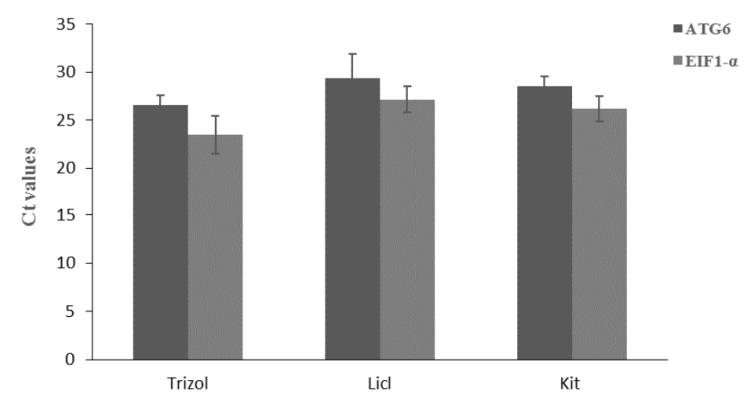

Fig. 5. Graph of cycle threshold $(\mathrm{Ct})$ values of samples tested by the real-time q-PCRfor ATG6 in N. benthamiana leaf samples harvested at $5 \mathrm{dpi}$ and extracted using either theTRIzol, $\mathrm{LiCl}$ or commercial kit methods. Total RNA was extracted using either theTRIzol, $\mathrm{LiCl}$ or commercial kit methods. Data were expressed as cycle threshold $(\mathrm{Ct})$ values. Then, Ct values of housekeeping gene EIFI- $\alpha$ and target gene $A T G 6$ was compared using three different RNA extraction methods by SYBR green real time q-PCR, each consisting of three biological and technical replicates. Error bars represent the standard deviation of the mean 


\section{Conclusions}

Although leaf patches of $N$. benthamiana were used, TRI reagent method can be particularly useful for anyone working with small leaf samples that are not amenable to multiple independent extractions. Overall, based on high total RNA yield, optimum absorbance ratios and q-PCR results, the TRIzol method was selected as the best for further studies.

\section{Acknowledgements}

The research received no specific grant from any funding agency in the public, commercial, or not-for-profit sectors.

\section{References}

Alemzadeh A, Fujie M, UsamiS, Yamada T (2005). Isolation of high-quality RNA from high-phenolic tissues of eelgrass (Zostera marina L.) by keepingtemperature low. Plant Molecular Biology Reporter 23(4):421.

Ballut L, Drucker M, Pugnière M, Cambon F, Blanc S, Roquet F, et al,, Badaoui $S$ (2005). HC-Pro, a multifunctional protein encoded by a plant RNA virus, targets the $20 S$ proteasome and affects its enzymatic activities. Journal of General Virology 86:2595-2603.

Brigneti G, Voinnet O, Wan-Xiang L, Ding SW, Baulcombe DC (1998). Viral pathogenicity determinants are suppressors of transgene silencing TheEMBO Journal 17(22):6739-6746.

Ding SW, Li H, Lu R, Li F, Li WX (2004). RNA silencing: a conserved antiviral immunity of plants and animals. Virus Research 102(1):109115.

Ding SW, Voinnet O (2007). Antiviral immunity directed by small RNAs. Cell 130(3):413-426.

Duncan DB (1951). A significance test for differences between ranked treatments in an analysis of variance. Virginia Journal of Science 2:171189.

Germundsson A, Savenkov EI, Ala-Poikela M, Valkonen JP (2007). VPg of Potato virus A alone does not suppress RNA silencing but affects virulence of a heterologous virus. Virus Genes 34(3):387-399.

Johansen LK, Carrington JC (2001). Silencing on the spot. Induction and suppression of RNA silencing in the Agrobacterium-mediated transient expression system. Plant Physiology 126(3):930-938.

Kasschau KD, Carrington JC (1998). A counter defensive strategy of plant viruses: suppression of posttranscriptional gene silencing. Cell95(4):461470.

Li F, Ding SW (2006). Virus counter defense: diverse strategies for evading the RNA-silencing immunity. Annual Review of Microbiology 60:503531.

Loulakakis KA, Roubelakis-Angelakis KA, Kanellis AK (1996). Isolation of functional RNA from grapevine tissues poor in nucleic acid content. American Journal of Enology and Viticulture 47(2):181-185.

Maciel BM, Dias JC, Romano CC, Sriranganathan N, Brendel M, Rezende RP (2011). Detection of Salmonella Enteritidis in asymptomatic carrier animals: comparison of q-PCR and bacteriological culture methods. Genetics and Molecular Research 10(4):2578-2588.
Nakagawa T, Kurose T, Hino T, Tanaka K, Kawamukai M, Niwa Y, Kimura T (2007). Development of series of gateway binary vectors, pGWBs, for realizing efficient construction of fusion genes for plant transformation. Journal of Bioscience and Bioengineering 104(1):3441.

Pirone TP, Blanc S (1996). Helper-dependent vector transmission of plant viruses. Annual Review of Phytopathology34(1):227-247.

Qu F, Morris TJ (2005). Suppressors of RNA silencing encoded by plant viruses and their role in viral infections. FEBS Letters 579(26):59585964.

Rajamäki ML, Mäki-Valkama T, Mäkinen K, Valkonen JPT (2004). Infection with potyviruses. In: Talbot NJ (Ed) Plant-Pathogen Interactions. Blackwell, Sheffield pp 68-91.

Redondo E, Krause-Sakate R, Yang SJ, Lot H, Le Gall O, Candresse T (2001). Lettuce mosaic virus (LMV) pathogenicity determinants in susceptible and tolerant lettuce varieties map to different regions of the viral genome. Molecular Plant-Microbe Interactions 14(6):804810.

Rojas MR, Zerbini FM, Allison RF, Gilbertson RL, Lucas WJ (1997). Capsid protein and helper component-proteinase function as potyvirus cell-to-cell movement proteins. Virology 237(2):283-295.

Roth BM, Pruss GJ, Vance VB (2004). Plant viral suppressors of RNA silencing. Virus Research 102(1):97-108.

Sáenz P, Salvador B, Simón-Mateo C, Kasschau KD, Carrington JC, García JA (2002). Host-specific involvement of the HC protein in the longdistance movement of potyviruses. Journal of Virology 76(4):19221931.

Sahana N, Kaur H, Basavaraj TF, Jain RK, Palukaitis P, Canto T, Praveen S (2012). Inhibition of the host proteasome facilitates Papaya ringspot virus accumulation and proteosomal catalytic activity is modulated by viral factor HC-Pro. Plos One 7(12), e52546 10.1371.

Sambrook J, Russell D (2001). Molecular Cloning: A Laboratory Manual. Cold Spring Harbor Laboratory Press (3rd ed), New York.

Schultz DJ, Craig R, Cox-Foster DL, Mumma RO, Medford JI (1994). RNA isolation from recalcitrant plant tissue. Plant Molecular Biology Reporter 12(4):310-316.

Urcuqui-Inchima S, Haenni AL,Bernardi F (2001). Potyvirus proteins: a wealth offunctions. Virus Research 74(1):157-175.

Voinnet $\mathrm{O}$ (2005). Induction and suppression of RNA silencing: insights from viral infections. Nature Reviews Genetics 6(3):206.

Wang Y, Gaba V, Yang J, Palukaitis P, Gal-On A (2002). Characterization of synergy between Cucumber mosaic virus and potyviruses in cucurbit hosts. Phytopathology 92(1):51-58.

Winfrey MR, Rott MA, Wortman AT (1997). Unraveling DNA: Molecular Biology for the Laboratory. Prentice-Hall, Upper Saddle River,NJ.

Zhu B, Gao KS, Wang KJ, Ke CH, Huang HQ (2012). Gonad differential proteins revealed with proteomics in oyster (Saccostrea cucullata) using alga as food contaminated with cadmium. Chemosphere 87(4):397403. 